\title{
Bildungsroman angolano: uma leitura de As aventuras de Ngunga, de Pepetela
}

\author{
Angolan Bildungsroman: a reading of Ngunga's \\ Adventures, by Pepetela
}

\section{Bildungsroman angoleño: lectura de Las aventuras de Ngunga, de Pepetela}

\author{
iD (9) Maria Ismênia Lima \\ Universidade Estadual da Paraíba (UEPB), Campina Grande, Paraíba, Brasil. \\ E-mail: ismenialima302@hotmail.com. \\ iD Francisca Zuleide Duarte de Souza \\ Universidade Estadual da Paraíba (UEPB), Campina Grande, Paraíba, Brasil. \\ E-mail: zuleide.duarte@hotmail.com.
}

Resumo: O presente artigo tem como objetivo analisar a obra de Pepetela, As aventuras de Ngunga, pela perspectiva do romance de formação, de modo a evidenciar as identidades dessa obra com esta categoria romanesca, bem como as particularidades que assume devido à realidade contextual enfatizada. Assim, defende-se a ideia de que As aventuras de Ngunga pode ser compreendida enquanto um Bildungsroman angolano, uma vez que apresenta a trajetória de formação do protagonista a partir das diversas circunstâncias de seu meio social, de forma que são cruciais em seu amadurecimento, necessário para o enfrentamento dos desafios propostos pela vida.

Palavras-chave: Bildungsroman. Angola. As aventuras de Ngunga.

\begin{abstract}
This article aims to analyze the work by Pepetela Ngunga's Adventures by the perspective of Bildungsroman, in order to highlight the identities from this work in this Romanesque category, as well as
\end{abstract}


the particularities that assumes due to contextual reality emphasized. Thus, argues the idea that Ngunga's Adventures can be understood as a Angolan Bildungsroman, whereas present the life path of the protagonist according to different circumstances from his social environment, in way there are crucial in his maturity, which it is necessary to face the challenges proposed by life.

Keywords: Bildungsroman. Angola. Ngunga's Adventures.

Resumen: El propósito de este artículo es analizar la obra de Pepetela Las aventuras de Ngunga desde la perspectiva de la novela de formación, con el fin de resaltar las identidades de esta obra con esta categoría novelística, así como las particularidades que asume por la realidad contextual enfatizada. Así, defiende la idea de que Las aventuras de Ngunga puede entenderse como un Bildungsroman angoleño, ya que presenta la trayectoria de formación del protagonista a partir de las distintas circunstancias de su entorno social, de una forma que resulta crucial en su madurez, necesaria para afrontar los retos de la vida.

Palabras-clave: Bildungsroman. Angola. Las aventuras de Ngunga.

Submetido em 30 de agosto de 2020.

Aceito em 13 de outubro de 2020.

Publicado em 04 de março de 2021. 


\section{Introdução}

O Bildungsroman ou "romance de formação" é um tipo de romance que apresenta para o leitor o percurso de vida de uma personagem e seu amadurecimento. Tem origem na Alemanha do século XVIII e a obra paradigma deste conceito é Os anos de aprendizado de Wilhelm Meister (2006), escrita por Johann Wolfgang von Goethe, que narra as experiências de vida do jovem burguês WiIhelm Meister, dividido entre as próprias ambições e as perspectivas da família e da sociedade da qual faz parte. Este livro foi tomado como modelo para o surgimento de muitas outras produções ficcionais, tanto no âmbito europeu quanto em outros territórios e espaços ao longo do tempo, que foram adquirindo contornos próprios de acordo com as realidades configuradas, ora convergindo ou afastando-se do romance de Goethe.

É nesse panorama que destacamos As aventuras de Ngunga, escrita por Pepetela e publicada na década de 1970. Esta obra tem como protagonista o garoto Ngunga, órfão em decorrência dos conflitos coloniais, que inicia um percurso de andanças e aprendizados por diferentes espaços do interior das terras de Angola no período da guerra pela independência. Em cada itinerário o jovem adquire novas experiências, as quais irão formá-lo e prepará-lo para a vida adulta. Nesse sentido, denotamos que As aventuras de Ngunga estabelece um diálogo com a tradição do Bildungsroman, ao propor-se como narrativa de uma vida em formação, que apresenta a problemática do confronto entre o indivíduo e a realidade de sua época, de seu amadurecimento gradual.

Por este viés, o presente artigo tem como objetivo desenvolver uma reflexão sobre As aventuras de Ngunga e analisá-la sob a perspectiva do romance de formação. Nesse sentido, pretendemos identificar as semelhanças e divergências da obra de Pepetela com esse tipo de romance. Para tanto, contamos com o anteparo teórico de autores como Marcelo Caetano (2006), Campos (2009) e Silva (2017) acerca da obra pepeteliana analisada, e Wilma Patricia 
Bildungsroman angolano: uma leitura de As aventuras de Ngunga, de Pepetela Maria Ismênia Lima • Francisca Zuleide Duarte de Souza

Maas (2000) e Maurício Mazzari (2018) no tocante aos estudos sobre o Bildungsroman.

Isto posto, partimos da ideia de que o livro As aventuras de Ngunga pode ser visualizado como um romance de formação, um Bildungsroman angolano, uma vez que o protagonista delineia um percurso envolto por aventuras e aprendizagens de diversas ordens, as quais possibilitam o seu amadurecimento. Em meio a toda uma configuração de conflitos, Ngunga desloca-se, desdobra-se e vivencia experiências diversas, que apontam para sua transformação ao fim da trama ficcional, algo que o aproxima do Bildungsroman.

Assimilar esse conceito, tão demarcado em sua origem por uma tradição literária situada à margem do eixo eurocêntrico, como é o caso da literatura angolana, é um desafio. Mas é também instigante, no sentido de promover novos olhares e perspectivas sobre o romance de formação, permitindo o seu desenvolvimento em novas roupagens, vinculado a outras vidas e histórias.

\section{As aventuras de Ngunga: um Bildungsroman?}

Dentre as possibilidades que podemos denotar em relação à literatura está a de que ela é capaz de abranger uma multiplicidade de perspectivas sobre os sujeitos na relação com o mundo e consigo mesmos, delineando vários itinerários, ora na busca por compreender a si, ora por apreender as circunstâncias de cunho social, cultural e histórico nas quais estão inseridos ou mesmo refletir sobre elas; de modo que pode haver o estabelecimento de pontes com a realidade presente ou de certa temporalidade. É tendo em vista estas concepções acerca das potencialidades das produções ficcionais que destacamos As aventuras de Ngunga, novela do escritor Pepetela, inserida no contexto literário angolano da década de 1970. 
Bildungsroman angolano: uma leitura de As aventuras de Ngunga, de Pepetela Maria Ismênia Lima • Francisca Zuleide Duarte de Souza

Esta obra narra a trajetória de Ngunga, um garoto órfão de treze anos que perde a família em razão dos conflitos armados resultantes da luta pela independência nacional angolana e, sozinho, empreende um percurso por vários contextos do interior de seu país, revelando os bastidores da guerra colonial, como também evidenciando os dilemas sociais e éticos (as convergências e divergências nos discursos e nas ações dos personagens) que permeiam os diferentes espaços com os quais entra em contato. Desta feita, o ponto essencial que almejamos enfatizar nesta obra é o caminho de aprendizagem empreendido por Ngunga através de suas andanças, que possibilitam o seu crescimento pessoal, bem como a sua preparação para enfrentar os desafios da vida adulta. Assim, para Campos (2009, p. 231-232):

\begin{abstract}
As aventuras de Ngunga reúne exemplarmente os temas da viagem, da guerrilha e da tradição. A viagem - metáfora do processo de iniciação por que deve passar o africano para atingir a maturidade - constitui, na narrativa de Pepetela, o viés que aglutina a guerrilha (aprendizagem de vida essencial no momento em que o texto é gerado) e a tradição ("concepção africana do mundo"2 que, sem os ranços e vícios que a corromperam, deve ser incorporada pelas novas gerações que representarão a identidade da nação em processo de construção).
\end{abstract}

A partir dessas considerações de Campos (2009), compreendemos que o transcurso de aprendizagem tecido nesta obra pepeteliana não apenas se debruça sobre Ngunga, mas também em relação à nação como um todo. Por esse viés, tem-se que o protagonista pode ser analisado não só em sua individualidade, mas também enquanto metáfora da nação que se projeta para o futuro e que está em processo construtivo da própria identidade. Presentifica-se em As aventuras de Ngunga, portanto, dois percursos: do protagonista em "tornar-se um guerrilheiro-modelo, através da conquista da integridade, do autoconhecimento e da consciência política" (CAMPOS, 2009, p. 230) e a da própria nação, sob um contexto sócio-histórico situado temporalmente, que revela as ideolo- 
Bildungsroman angolano: uma leitura de As aventuras de Ngunga, de Pepetela Maria Ismênia Lima • Francisca Zuleide Duarte de Souza

gias vigentes e as bases, cujas relações sociais se dão, como também suas fragilidades. Assim, o jovem Ngunga "[...] em função do contexto em que é gestado, espelha todas as virtudes essenciais ao modelo de identidade angolana com que o escritor em questão deseja ver formadas as novas gerações de sua terra [...]" (CAMPOS, 2009, p. 230), o que revela na narrativa um ideal utópico forjado a partir de um romantismo revolucionário.

Em análise mais atenta do modo em que se dá o delineamento ficcional da figura protagonística de Ngunga e sua trajetória formativa no mundo, podemos estabelecer eixos de proximidade com um tipo específico de narrativa denominado de "Bildungsroman" ou "romance de aprendizagem" ou "romance de formação" que tem uma tradição na historiografia literária universal, principalmente a europeia, tendo em vista que se originou sob esse contexto, precisamente o alemão, e em um tempo específico, o século $X V I I I$. Mas, difundiu-se também em outros meios ao longo do tempo e assumiu diferentes roupagens e configurações semânticas a partir de novas realidades, a exemplo das literaturas nacionais americanas e africanas.

Deste modo, defendemos neste artigo uma possível chave de leitura de As aventuras de Ngunga pela perspectiva do romance de formação, por apresentar o caminho de desenvolvimento de um personagem frente às adversidades e percalços do mundo de forma a adquirir conhecimentos que o forjam para a vida adulta, além de outros pontos importantes, como a abordagem das configurações sócio-político-culturais de uma época, e os ensinamentos ou reflexões que o leitor pode empreender a partir dos discursos amalgamados pela obra. Ao abordarmos As aventuras de Ngunga como um romance, estamos adotando a mesma concepção de estudiosos como Marisa Lajolo (1993) e Marcelo Caetano (2006), que o consideram desse modo, bem como evidenciam a potencialidade discursiva dessa obra e sua relevância para a literatura de Angola. Segundo Caetano (2006, p. 44): 
A narrativa que constitui As aventuras de Ngunga pode ser lida da perspectiva desse "choque repentino" de que fala Bhabha, ou seja, sob o ponto de vista da irrupção de forças que se opõem ao status quo - que é também pedagógico - e instauram domínios de resistência e reafirmação simbólica da identidade. [...] realiza-se como provocação desarmônica aos princípios ideológicos coloniais. Além disso, ela inspira a discussão sobre uma nova pedagogia que sustentaria a trama simbólica, da resistência ao colonizador e da construção de uma nova identidade definindo os ânimos e os sentidos possíveis da história de Angola. (CAETANO, 2006, p. 44, negrito do autor)

No artigo As aventuras de Ngunga: entre a novela e o romance (2017), Marcos Vinicius Caetano da Silva traz a discussão sobre a possível classificação desta obra pepeteliana, tendo em vista sua dimensão e o tom potencializador engendrado pelo enredo. Nesse sentido, o autor mostra que ao ser lançada no Brasil, em 1983, foi classificada genericamente de "ficção angolana" (SILVA, 2017, p. 219), todavia, conforme salientamos anteriormente, foram nomes como os de Lajolo e, posteriormente, Caetano (2006) que o consideraram em suas pesquisas como romance e de formação. A edição que utilizamos denomina a obra de "romance angolano" e contém 86 páginas, assim, o que caracterizaria As aventuras de Ngunga como uma novela seria a sua extensão. Acerca do enredo não se poderia dizer o mesmo, uma vez que o que se constata é uma intensidade na construção ideológica e no encadeamento das ações realizadas por Ngunga em suas andanças, o que aproximaria o livro do gênero romance, o qual, segundo Antônio Candido (2009), "elabora conscientemente uma realidade humana, que extrai da observação direta, para com ela construir um sistema imaginário e mais durável" (CANDIDO, 2009, p. 429).

Segundo Lajolo (1993), ao escrever esta obra Pepetela teria se inspirado nos romances educativos ocidentais, mas, por outro lado, se afastaria de um encaixe em modelos tradicionais europeus, ao evidenciar o caráter oral e o universo africano, por meio de "uma linguagem que 
Bildungsroman angolano: uma leitura de As aventuras de Ngunga, de Pepetela Maria Ismênia Lima • Francisca Zuleide Duarte de Souza

guarda marcas fortes da oralidade das narrativas populares, sugerindo uma recepção de texto que se afasta da recepção livresca, escolar, ocidental e que dá sentido emergencial e menos pitoresco àquele modo de produção sob as árvores e sob o sol" (LAJOLO, 1993, p. 90 apud SILVA, 2017, p. 222), além de preservar a oralidade, traz capítulos bastante curtos, cujos fechamentos assemeIham-se às formas rituais presentes no encerramento de narrativas populares (LAJOLO, 1993 apud SILVA, 2017). Assim, constata-se que As aventuras de Ngunga parte de pressupostos que remontam aos romances educativos, mas, em seu desenvolvimento, adquire singularidades próprias adequadas ao horizonte cultural em que está situado.

\section{Sobre o Bildungsroman: algumas considerações}

O romance de aprendizagem ou Bildungsroman é objeto de pesquisa de muitos estudiosos no meio acadêmico brasileiro, dentre eles, destacaremos as contribuições formuladas por Wilma Patricia Maas em O cânone mínimo - O Bildungsroman na história da literatura (2000). Neste estudo, a pesquisadora afirma que, originalmente, "Trata-se de uma forma literária de cunho eminentemente realista, com raízes fortemente vincadas nas circunstâncias históricas, culturais e literárias dos últimos trinta anos do século XVIII europeu" (MAAS, 2000, p. 13), fenômeno "tipicamente alemão" (MAAS, 2000, p. 19). Ou uma forma de romance que "representa a formação do protagonista em seu início e trajetória em direção a um grau determinado de perfectibilidade" e que também "promove a formação do leitor através dessa representação, de uma maneira mais ampla do que qualquer outro tipo de romance." (MORGENSTERN, 1988, p. 64 apud MAAS, 2000, p. 46).

Essa é uma definição tradicional elaborada por Karl Morgenstern (1770-1852), professor de Filologia Clássica na Universidade de Dorpat ${ }^{1}$ e criador do termo na primeira década do século XIX (posteriormente difundido no meio acadêmico pelo filósofo Wi-

$\overline{1 \text { Atual Tartu, capital }}$ da Estônia. 
Bildungsroman angolano: uma leitura de As aventuras de Ngunga, de Pepetela Maria Ismênia Lima • Francisca Zuleide Duarte de Souza

Ihelm Dilthey em 1870). O autor evidencia as proposições elementares em relação a esta categoria de romance, a saber, a representação de um percurso realizado por um personagem até adquirir experiências que promoverão seu desenvolvimento pessoal até um estágio "ideal" e, neste movimento, a influência que exerceria sobre o leitor. Essas considerações de Morgenstern estão inseridas sob a discussão teórica relativa às especificidades da epopeia e do romance burguês. Enquanto na epopeia vislumbramos o protagonista agindo em direção ao exterior, provocando alterações significativas no mundo; no romance a ênfase é mais em relação aos homens e ao ambiente agindo sobre o protagonista, esclarecendo a representação de sua gradativa formação interior (MORGENSTERN, 1988 apud MAAS, 2000, p. 46-47).

Nesta explanação, cabe destacarmos a fala de Mazzari (2018, p. 17), para quem:

[...] "formação" não é um mero sinônimo para "cultura", "instrução", "erudição" etc. Buscar sua "formação" significa também buscar uma desenvoltura nos assuntos mundanos, fazer novas experiências, aproximar-se o máximo possível de uma (sempre inatingível, porém) "maestria de vida". "Formação" não significa, portanto, apenas adquirir novos conhecimentos, mas também redimensionar o já sabido, passar em revista, criticamente, as opiniões, os juízos e "pré-juízos", conceitos e "pré-conceitos" e, desse modo, estar inserido num processo de contínuas transformações.

Essa fala de Mazzari é bastante esclarecedora no tocante à significação de formação ou aperfeiçoamento humano compartilhados pelo Bildungsroman. O percurso formativo envolve algo além da inserção de um sujeito em instituição educativa ou contato com mentores, professores, pois abarca uma percepção mais ampla no sentido de que capta o sujeito nas malhas da vida, a partir de experiências várias, as quais desencadeiam aprendizados e transformações contínuas. Nesse sentido, podemos considerar também as contribuições de Bakhtin (1992, p. 240), que analisa o romance 
Bildungsroman angolano: uma leitura de As aventuras de Ngunga, de Pepetela Maria Ismênia Lima • Francisca Zuleide Duarte de Souza

de formação na perspectiva realista e imbuído pelas configurações históricas, afirmando que:

O homem se forma ao mesmo tempo que o mundo, reflete em si mesmo a formação histórica do mundo. O homem já não se situa no interior de uma época, mas na fronteira de duas épocas, no ponto de passagem de uma época para outra. Essa passagem efetua-se nele e através dele. Ele é obrigado a tornar-se um novo tipo de homem, ainda inédito. É precisamente a formação do novo homem que está em questão. [...] São justamente os fundamentos da vida que estão mudando e compete ao homem mudar junto com eles [...].

Bakhtin traz a lume a questão da historicidade como elemento potencializador para os estudos sobre o Bildungsroman, ao considerar de suma relevância a análise da relação entre o sujeito e as configurações históricas que o rodeiam, denotando, a partir disso, as suas possíveis influências na constituição humana do próprio sujeito. Assim, ao situar-se em meio a um contexto em transformação, ele [o sujeito] também necessita transformar-se, e isso promove o crescimento individual e a adequação aos devires do mundo. Nesse sentido, salientamos que o ponto de vista que assumimos neste artigo consiste justamente no histórico, ou seja, analisar em As aventuras de Ngunga o entrelaçamento entre o protagonista e as circunstâncias históricas que configuram o contexto social em que ele está inserido, bem como as influências deste para a sua constituição humana.

Isto posto, dando prosseguimento a esta explanação, temos que o surgimento do romance de aprendizagem ou Bildungsroman dá-se em meio ao fortalecimento do romance enquanto gênero, pois ele "deixa de ser considerado uma literatura menor, ou mesmo uma literatura marginal, voltando-se para o centro do conjunto dos gêneros literários" (MAAS, 2000, p. 58). A marginalidade direcionada ao romance dava-se por este ser comumente relacionado à ideia de conter somente "histórias de amor", o que Ihe denotava um ca- 
ráter negativo frente aos gêneros mais valorizados. Aliada a essa questão está também a ascensão da burguesia na sociedade alemã, classe que vislumbrou no romance a possibilidade de difundir suas ideologias e desejos. Assim, temos então o Bildungsroman como uma categoria demarcada espacial e temporalmente, que retrata o "espírito de época" e está voltado para a questão do nacionalismo moderno e da emancipação burguesa (MAAS, 2000, p. 24).

Nesse sentido, a obra paradigmática para o Bildunsroman é o romance do alemão Johann Wolfgang von Goethe, Os anos de aprendizado de Wilhelm Meister (Wilhelm Meisters Lehrjahre - 17951796). A narrativa (composta por oito livros) aborda a vida do jovem burguês Wilhelm Meister desde a sua juventude até o início da maturidade, período marcado pela busca em desenvolver plenamente suas potencialidades. Com esse propósito, retira-se do meio familiar para unir-se a uma companhia de teatro e viajar pelas cidades e povoados da Alemanha. A partir disso, o seu percurso é trilhado por aventuras, encontros e desencontros, ligações amorosas, além do contato com burgueses, nobres, poetas e artistas, atores itinerantes, aventureiros, membros de uma sociedade secreta (a Sociedade da Torre ou Turmgesellschaft), dentre outros, denotando um painel da sociedade da época, sua dinâmica de classes e as aspirações da burguesia. Assim, conforme Lukács, que define esta obra de 'romance de educação', "A estrutura dos homens e destinos no Wilhelm Meister define a construção do mundo social que os circunda" (LUKÁCS, 2000, p. 144).

Os anos de aprendizado de Wilhelm Meister pode ser compreendida assim, como símbolo das transformações concernentes a uma determinada época e em consonância com os pressupostos em voga. Ela é paradigmática do Bildunsroman e aponta para concepções sobre as experiências humanas e seu deslocamento ao longo da vida, tecendo, nas malhas da ficção, possíveis reflexões sobre a relação indivíduo e sociedade.

Analisar As aventuras de Ngunga sob a ótica do romance de formação é considerar não só suas identidades, mas também as especificidades que a diferem do paradigma europeu alemão, tendo em 
Bildungsroman angolano: uma leitura de As aventuras de Ngunga, de Pepetela Maria Ismênia Lima • Francisca Zuleide Duarte de Souza

vista se tratar de uma outra perspectiva, a africana e, mais ainda, a angolana, localizada em uma certa temporalidade e conjuntura no tocante às ideologias e aos aspectos culturais, sociais e políticos. As realidades propostas pela obra configuram uma outra visão acerca do mundo, conforme passaremos a constatar a seguir.

\section{As aventuras de Ngunga: 0 Bildungsroman Angolano}

Em As aventuras de Ngunga conhecemos parte da vida do protagonista Ngunga, um pequeno itinerante sobre as terras do interior de Angola. A partir de suas experiências, somos conduzidos aos bastidores de uma nação em processo de descoberta de si, da própria identidade em meio ao caos de uma guerra cruel, em sua potencialidade, capaz de destruir territórios, comunidades e laços familiares, deixando como resultantes o caos e inúmeras incertezas e, no caso de Ngunga, a orfandade.

Seu contato com as durezas da vida acontece precocemente, por volta dos nove anos perde a família durante ataque dos inimigos colonialistas: "Os pais foram surpreendidos pelo inimigo, um dia, nas lavras. Os colonialistas abriram fogo. O pai, que já era veIho, foi morto imediatamente. A mãe tentou fugir, mas uma bala atravessou-lhe o peito. Só ficou Mussango, que foi apanhada e levada para o posto". (PEPETELA, 2013, p. 10). Esse acontecimento é determinante para o início da jornada de Ngunga, que a partir de então terá de cuidar de si mesmo. Constatamos, assim, um evento de perda como marco introdutório do protagonista no caminho de vivências posteriores. Essa circunstância diverge da que se constata em Os anos de aprendizado de Wilhelm Meister, pois o percurso do jovem Meister tem início por sua própria vontade e ação, ao abandonar a abastada casa paterna para fugir com uma atriz e seguir um grupo de teatro, deixando para trás o conforto e um futuro certo como comerciante.

Para Ngunga, a família, a base de afetos foi-lhe tirada bruscamente, sobrando, portanto, a solidão e desamparo, mesmo que 
Bildungsroman angolano: uma leitura de As aventuras de Ngunga, de Pepetela Maria Ismênia Lima • Francisca Zuleide Duarte de Souza

tenha recebido alguns cuidados de conhecidos por certo tempo, como é o caso de Nossa Luta, que abrigou-Ihe em sua casa antes de partir para a guerrilha e da velha Ntumba, que antes de morrer fornecia-Ihe algum alimento. Nessa perspectiva, Oliveira (2013, p. 04-05) corrobora a ideia de que "As aventuras de Ngunga metaforizam o ritual de passagem dos "camaradas" que desde muito jovens vivenciam a experiência da guerra. Ngunga simboliza o individual, mas também o coletivo, pois o sonho de liberdade, assim como o menino, cresce e amadurece na hora precisa."

Diferentemente de Meister, que tinha uma vida de abastança e toda sorte de comodidades, aos treze anos os únicos bens que Ngunga possuía eram "Um cobertor de casca de árvore, um frasco vazio, um pau para limpar os dentes, a fisga ao pescoço e a faca à cinta, eis toda a sua riqueza" (PEPETELA, 2013, p. 16), isto é o que constitui a mala de viagem para sua aprendizagem enquanto sujeito de um país em ebulição. Nesse sentido, ele perfaz um caminho de descobertas acerca de si e da própria nação, ao evidenciar questões constituintes desta naquela época, a segunda metade do século $X X$, em contexto da guerra colonial, a exemplo da relação entre os guerrilheiros e as comunidades angolanas, assim como as divergências no comprometimento ético dos líderes perante a organização das comunidades na luta pela independência. Como pode ser verificado na passagem de Ngunga pela aldeia do líder tribal, o presidente Kafuxi, que se mostra corroído pelo poder e ganância advindos da posição social que ocupa:

Afinal o velho estava a aproveitar. Era mais rico que os outros, pois
tinha mais mulheres. Além disso, tinha o Ngunga que trabalhava
todo o dia e só comia um pouco. Uma parte do seu trabalho,
uma canequita talvez, ia para os guerrilheiros. Algumas canecas
iam para a sua alimentação. E o resto? As quindas de fubá que
ele ajudava a produzir, o que pescava no Kuando, o mel que
tirava dos cortiços? Tudo isso ia para o velho, que guardava para
trocar com pano. Quando chegava um grupo de guerrilheiros ao
kimbo, Kafuxi mandava esconder a fubá. (PEPETELA, 2013, p. 21) 
A figura de Kafuxi insere-se na narrativa como elemento destoante do projeto nacional propagado. A nação que estava sendo forjada não poderia admitir mais comportamentos como o do líder tribal, que procurava beneficiar a si mesmo em detrimento de seus compatriotas. A luta interessava-o até o instante em que não prejudicasse seus interesses pessoais. Ciente deste comportamento, Ngunga age, ao perceber que "[...] as palavras nada valiam" (PEPETELA, 2013, p. 22) e "Foi ao celeiro, encheu uma quinda grande com fuba, mais um cesto. Trouxe tudo para o sítio onde estavam as visitas e o presidente Kafuxi. Sem uma palavra, pousou a comida no chão. Depois foi à cubata arrumar as suas coisas" (PEPETELA, 2013, p. 22).

A passagem pela aldeia do presidente Kafuxi ensina ao jovem Ngunga que nem todos, mesmo aqueles que vivem sob a condição colonial, os seus semelhantes, estão engajados no bem comum, muita coisa ainda precisaria ser revista para que uma nova sociedade pudesse fincar suas raízes plenamente. Assim, nem sempre o discurso é a melhor arma, a ação também é um recurso válido na resolução de problemas, e é justamente o que Ngunga faz nesta e em outras ocasiões ao longo de seu percurso. Diante disto, o jovem, "duplo do Quixote em sua utopia de consertar o mundo, prossegue viagem, tendo, porém, aprendido a desconfiar de valores que considerava inquestionáveis: a veracidade da palavra e a integridade dos mais velhos" (CAMPOS, 2009, p. 234).

Um certo ideal de liderança é percebido por Ngunga ao chegar na Seção de Guerrilheiros do Comandante Mavinga, membro do MPLA. Esse personagem, diferentemente de Kafuxi, mostra-se apto para cuidar do povo e liderar as ações táticas na guerrilha, apesar de não ser "[...] alto e forte", mas apenas "[...] um homem ainda novo, pequeno e magro" (PEPETELA, 2013, p. 25). Mavinga é a representação do líder necessário naquele momento, alguém do povo, que não possuía características extraordinárias como os heróis das grandes narrativas, mas um ser humano igual aos demais, sendo que sua aptidão estava fixada em seu caráter. 
Mavinga torna-se uma referência para o protagonista, assim como o professor União, que o garoto conhece ao entrar para a escola. Devido a sua coragem e inteligência, Mavinga afirma que futuramente Ngunga será um bom guerrilheiro, mas para isto, precisaria primeiramente, aprender a ler e escrever, “[...] para não ser como nós." (PEPETELA, 2013, p. 33). Há aqui a perspectiva do saber escolar como elemento emancipador do sujeito, sem ele Ngunga não estaria completamente pronto para ser um guerriIheiro-modelo, podendo ser facilmente manipulado por ideologias distorcidas e aprisionadoras, semelhantes àquelas que embasavam a estrutura colonial. Para fugir a isto é que a ida à escola se fazia necessária.

No tempo do colonialismo, ali nunca tinha havido escola, raros eram os homens que sabiam ler e escrever. Mas agora o povo começava a ser livre. O Movimento, que era de todos, criava a liberdade com as armas. A escola era uma grande vitória sobre o colonialismo. (PEPETELA, 2013, p. 34)

O regime colonial seria desconstruído por meio das armas e do conhecimento, aliados essenciais neste contexto histórico. A liberdade seria alcançada de dois modos: com a luta efetiva nas zonas de guerra, e no ambiente escolar, através do aprendizado pelas crianças, futuro da nação. A instituição escolar delineia-se na narrativa pepeteliana como símbolo de resistência no enfrentamento de forças contrárias, a partir de onde haveria o entendimento da revolução corrente naquele momento e seria formado também o homem novo, necessário para os novos tempos que haveriam de chegar.

Apesar da ênfase dada ao ambiente escolar na narrativa, a passagem de Ngunga por esse espaço é interrompida pela guerra. Certa manhã, ele e o professor União são repentinamente atacados perto da escola por colonialistas, e é neste episódio que Ngunga envolve-se efetivamente no conflito armado, atua como um pioneiro, um menino-soldado: "Estavam a tomar o mata-bi- 
Bildungsroman angolano: uma leitura de As aventuras de Ngunga, de Pepetela Maria Ismênia Lima • Francisca Zuleide Duarte de Souza

cho, quando tudo começou. Um estrondo enorme, logo seguido de intenso fogo de armas ligeiras. União só teve tempo de pegar na arma e saltar para trincheira gritando: - Vem, Ngunga, vem! Ngunga imitou-o." (PEPETELA, 2013, p. 45). Apesar de resistirem bravamente, não conseguem conter as investidas dos inimigos e são capturados: "As lágrimas corriam dos olhos cegos de Ngunga. Não era medo. Era só raiva de não ter uma granada. União, adormecido, não sentiu nada do que se passou. Mas Ngunga sofreu toda a humilhação da derrota." (PEPETELA, 2013, p. 48).

Com esse episódio Ngunga mata pela primeira vez, descobre novamente o quanto é difícil lutar pela própria vida, algo que para ele não é novidade, tendo em vista que já o faz desde cedo. O diferencial aqui é ter pego em armas e lutado de modo efetivo, o que até então não havia acontecido. A partir disso, fortalece ainda mais para o jovem o desejo de defender seu povo, lutar em prol de um bem comum, a liberdade de todos.

Já na prisão, fica sabendo que, mesmo castigado pelos colonialistas, o professor União não revelou os planos dos guerrilheiros e nem denunciou o amigo, comandante Mavinga. Este gesto de caráter despertou em Ngunga a admiração por seu professor, o qual compara ao colega de cela, Chitangua, que foi responsável por denunciá-los: “[...] União, sim, União era um homem. Combateu até o fim e sempre preocupado com a salvação de Ngunga. E agora recusava ajudar os tugas a apanharem o comandante Mavinga. União era seu professor e amigo: o orgulho fez Ngunga esquecer o sofrimento" (PEPETELA, 2013, p. 51).

O professor União revela-se como uma figura de caráter para o pequeno soldado, o qual, sabendo que ele está em sofrimento planeja ajudá-lo, mas tem o plano frustrado por não saber ler: "Se soubesse escrever... Sim, se soubesse escrever, podia meter um bilhetinho na cela de União e combinarem juntos a fuga. [...] Pela primeira vez, Ngunga deu razão ao professor que Ihe dizia que um homem só pode ser livre se deixar de ser ignorante" (PEPETELA, 2013, p. 54). Sem poder agir, vê seu amigo ser transferido para outro lugar, mas, antes disso, é lembrado de sua missão: “Nunca 
Bildungsroman angolano: uma leitura de As aventuras de Ngunga, de Pepetela Maria Ismênia Lima • Francisca Zuleide Duarte de Souza

te esqueças de que és um pioneiro do MPLA². Luta onde estiveres, Ngunga!" (PEPETELA, 2013, p. 55).

Através de sua inserção nesses espaços, Ngunga revela ao leitor não só os bastidores do território inimigo, no contato com suas lideranças, mas também mostra os discursos e posicionamentos contraditórios de outros angolanos, seus semelhantes, como por exemplo, os G.E., soldados angolanos que lutavam no exército português contra seu próprio povo, e o cozinheiro do chefe da PIDE, que apresentava um discurso de resignação e descrença pela luta contra o colonialismo. Para o jovem Ngunga esses comportamentos ainda são incompreensíveis, não há a percepção da força exercida pelas estruturas ideológicas disseminadas pelo regime colonial. Para o jovem pioneiro havia muito o que ser compreendido, o mundo desnudava-se em cada nova situação.

Isto posto, antes de fugir para encontrar Mavinga, Ngunga assassina o chefe da PIDE (Polícia Internacional e de Defesa do Estado), para o qual trabalhou como criado: "Lavava o chão, servia a comida, lavava as panelas." (PEPETELA, 2013, p. 53) e sai perdido pela mata: “E correu para a liberdade, para os pássaros, para o mel, para as lagoas azuis, para os homens. Atrás de si ficava o arame farpado, o mundo dos patrões e dos criados" (PEPETELA, 2013, p. 58).

Outro ponto decisivo na vida do protagonista é a sua passagem pela aldeia da jovem Uassamba, quarta mulher do velho Chipoya. Neste episódio, o sentimento amoroso surge pela primeira vez. Apaixonado, as esperanças de Ngunga são frustradas pela condição da moça, que já é comprometida. Nesta perspectiva, destacamos também que na narrativa de Goethe, há o retrato das ligações e desencontros amorosos vividos pelo jovem Wilhelm Meister. Até o momento de união com a jovem Natalia, o protagonista relaciona-se também com as atrizes Marianne e Philine e com Therese, são relacionamentos que, mesmo frustrados e alguns até efême-

2 Sigla do Movimento Popular de Libertação de Angola, grupo que lutou pela independência de Angola, transformando-se num partido político após a Guerra de Independência de 1961-74. Governa o país desde 1975. Informação disponível em: https:// www.dw.com/pt-002/movimento-popular-de-liberta\%C3\%A7\%C3\%A3o-de-a). 
ros, estabelecem-se como experiências para o protagonista, assim como ocorre com Ngunga.

Na obra de Pepetela vemos que o casamento da amada Uassamba surge como empecilho para os desejos do menino-soldado: "Porque o Mundo era assim? Tudo o que era bonito, bom, era oprimido, esmagado, pelo que era mau e feio. Não, não podia. Uassamba, tão nova, tão bonita, com aquele velho? Lá porque ele a comprara à família? Como um boi que se compra ou uma quinda de fuba?" (PEPETELA, 2013, p. 77). Esta paixão não concretizada apresenta-se como um descaminho, algo não realizável devido às circunstâncias. Há, nessa ocasião, uma crítica frente a uma prática da tradição cultural angolana, o alembamento, espécie de dote oferecido pelo homem à família da noiva.

Essa tradição é questionada por Ngunga, que chama atenção para o fato de que certos princípios e valores enraizados necessitam ser revistos, em prol da liberdade dos sujeitos, neste caso, as mulheres. A partir disto, constatamos que “[...] a construção do novo país não implica apenas uma luta com o colonizador, mas também um combate interno às velhas mentalidades" (CAETANO, 2006, p. 45) para uma possível realidade pós-colonial. Isto é percebido pelo jovem que, "Tinha vontade de gritar, de insultar o Chipoya, os pais de Uassamba, os velhos que defendiam os costumes cruéis, os novos que não tinham coragem de os destruir" (PEPETELA, 2013, p. 82), todavia, seguindo o conselho de seu amigo, o comandante Mavinga, visualiza na escola a possibilidade de aprendizagem (especializada) que irá prepará-lo para agir no futuro em busca das mudanças necessárias à sociedade.

Assim, a caminhada que se apresenta para o protagonista é simbolizada com a mudança de nome, que não é revelado pelo narrador, somente a jovem Uassamba o sabe. Finda-se a estória para o leitor, mas é somente o início de uma nova fase na vida de Ngunga, que deixa "morrer" o pequeno órfão e abre-se para a juventude e a vida adulta. No paradigmático Os anos de aprendizado de Wilhelm Meister, o desejo de tornar-se ator surge como um sonho no início da jornada de Meister, mas ao longo da narrativa 
Bildungsroman angolano: uma leitura de As aventuras de Ngunga, de Pepetela Maria Ismênia Lima • Francisca Zuleide Duarte de Souza

é percebido como uma idealização romântica de seus anos de juventude, a realidade prática o direciona para um outro percurso e isto desencadeia nele novas atitudes e anseios. Além disso, destacamos também que o protagonista de Goethe inicia sua trajetória como um filho e torna-se pai ao final da narrativa, encerrando temporariamente seu ciclo de aprendizagem.

Isto posto, tanto Wilhelm Meister quanto Ngunga, cada um em seu contexto (a Alemanha no séc. XVIII e a Angola colonial na segunda metade do séc. XX), têm um percurso marcado por acontecimentos que favorecem um amadurecimento, bem como novas perspectivas sobre a existência.

\section{Considerações finais}

A partir das explanações realizadas neste artigo verificamos que As aventuras de Ngunga pode ser lido como um Bildungsroman angolano, pois delineia na margem ficcional o percurso de aprendizagens do menino Ngunga e sua inserção na sociedade de seu tempo, revelando bastidores e paisagens socioculturais e políticas formadoras de um contexto em específico. É uma narrativa que se distancia temporal e espacialmente do modelar Os anos de aprendizado de Wilhelm Meister, pois o contexto europeu cede lugar ao espaço africano, as temporalidades são outras, as ideologias também o são, em certa medida.

Neste comparativo, denotamos a presença de um caráter nacional que permeia ambas as obras e apontam para as dinâmicas que rodeiam a sua própria constituição. A obra de Goethe marca o surgimento de um tipo específico de romance que fincou suas bases nas literaturas do Ocidente e continua até a contemporaneidade, transformando-se e assumindo novas roupagens. Já As aventuras de Ngunga nasce no seio de uma produção literária situada à margem do eixo eurocêntrico e que acompanha os discursos e os processos históricos vivenciados pela nação. Assim, conceitos como liberdade, identidade e independência, em voga na contex- 
Bildungsroman angolano: uma leitura de As aventuras de Ngunga, de Pepetela Maria Ismênia Lima • Francisca Zuleide Duarte de Souza

tualização social, também perpassam os discursos ficcionalizados pelos escritores em Angola. Há, portanto, um sistema literário em ascensão e autores engajados em torná-lo símbolo desse país.

Em suas aventuras, Ngunga depara-se com caminhos de aprendizagem árduos e desafiadores, os quais forjam, de certa forma o homem que ele será. Ideais como a amizade, a honestidade e a solidariedade são focalizados juntamente à crença em um mundo mais justo e acolhedor, algo que as aventuras e os percalços fizeram o pequeno órfão desejar ainda mais. Finalizadas as primeiras experiências com a vida, “Um homem tinha nascido dentro do pequeno Ngunga" (PEPETELA, 2013, p. 83) e isto demarca a abertura para novas aprendizagens.

\section{Referências}

BAKHTIN, M. Estética da Criação Verbal. São Paulo: Martins Fontes, 1992.

CAETANO, Marcelo José. A pedagogia da esperança em As aventuras de Ngunga. Scripta. Belo Horizonte, n. 19, p. 43-53, 2006.

CAMPOS, Maria do Carmo Sepúlveda. As aventuras de Ngunga: Nas Trilhas da Libertação. In: CHAVES, Rita e MACÊDO, Tania. (orgs.).

Portanto... Pepetela. São Paulo: Ateliê Editorial, 2009.

CANDIDO, Antonio. "A personagem do romance". In: CANDIDO, Antonio. et al. A personagem da ficção. 12a . ed. São Paulo: Perspectiva, 2009.

GOETHE, Johann Wolfgang von. Os anos de aprendizagem de Wilhelm Meister. Tradução de Nicolino Simone Neto; apresentação de Marcus Vinicius Mazzari; posfácio de Georg Lukács - São Paulo: Editora 34, 2006.

LUKÁCS, Georg. A teoria do romance. São Paulo: Duas Cidades; Editora 34, 2000. MAAS, Wilma Patrícia Marzari Dinardo. 0 cânone mínimo - 0 ‘Bildungsroman' na história da literatura. São Paulo: Editora UNESP, 2000. 
Bildungsroman angolano: uma leitura de As aventuras de Ngunga, de Pepetela Maria Ismênia Lima • Francisca Zuleide Duarte de Souza

MAZZARI, M. Os anos de aprendizado de Wilhelm Meister: “Um magnífico arco-íris" na história do romance. Literatura e Sociedade, v. 23, n. 27, p. 12-30, 11, 2018.

OLIVEIRA, Jurema. O romance em Angola: ficção e história em Pepetela. In: XXVII SIMPÓSIO NACIONAL DE HISTÓRIA: CONHECIMENTO HISTÓRICO E DIÁLOGO SOCIAL, 2013, Natal-RN. Anais, Natal: Anpuh, 2013. p. 01-11.

PEPETELA. As aventuras de Ngunga. Belo Horizonte: Nandyala, 2013.

SILVA, Marcos Vinicius Caetano da. As Aventuras de Ngunga: entre a novela e o romance. Papéis: Revista do Programa de Pós-graduação em Estudos de linguagens, v. 21, n. 42, p. 218-229, 2017. 